УКД 130.2

\author{
Чмихун С. Е., Більчук Н. Л.
}

doi: $10.32620 / g c h .2019 .1 .10$

\title{
ЗМІ ЯК АГЕНТ НЕЯВНОГО ПРИМУСУ ПОВЕДІНКОВОЇ КУЛЬТУРИ
}

У статті проаналізовано місие й роль ЗМI у формуванні стереотипів поведінкової культури. Під час дослідження було зроблено висновок про подвійний характер продукиї масмедіа, які, з одного боку, неявно впливають на розповсюдження правил і норм поведінки, а з другого - можуть сприяти спрощенню моралі й потурати непристойному, низькому, вульгарному.

Ключові слова: навіювання, маніпулячія, масмедіа, поведінкова культура.

The article analyzes the place and role of mass media in the formation of stereotypes of behavioral culture. In the course of the study, it was concluded that the mass media are two-sided, which, on the one hand, implicitly influence the spread of rules and norms of conduct, and on the other hand, they can contribute to the simplification of morality and indulge vulgar, obscene, lowlying and undeclared behaviour.

Keywords: suggestion, manipulation, mass media, behavioral culture.

В статье анализируется роль и место СМИ в формировании стереотипов поведенческой культуры. В результате исследования сделан вывод про двойственный характер продукции масс-медиа: с одной стороны, они неявно влияют на распространение правил и норм поведения, а с другой - могут способствовать упрощению морали, потворствуя пошлому, низкому, вульгарному.

Ключевые слова: внушение, манипуляция, масс-медиа, поведенческая культура.

\footnotetext{
Афишные тумбы, возможно,

В чем-то сродни маякам:

Их дождь поливает безбожно, Ветер сечет по бокам.

Но как их пестро наряжают! И средь городской кутерьмь Сулят они, ржут, угрожают Илгут еще хлеще, чем мы.
}

Иоахим Рингельнац

Унікальністю сьогодення $є$ те, що моральна культура перебуває під значним впливом засобів масової інформації. Такий феномен соціальної комунікативності має особливу здатність виявляти, зберігати й трансформувати інформацію, зокрема, про стереотипи культурної поведінки. Наразі засоби масової інформації здатні не тільки знайомити людину з основними формами поведінкової культури й спілкування, а й надавати знання, освіту, пропонувати рольові сценарії та форми креативної поведінки, при цьому охоплюючи максимально широкі верстви реципієнтів: від дипломатичних протоколів і політичних стратегій до сфер повсякденного й інтимноособистісного життя. У цьому розумінні об’єктом уваги ЗМІ стає наявне буття 
людини, у якому не залишається нічого потаємного, невимовного, особистісного. Таким чином, норми схеми особистісного буття нібито втрачають конкретного адресата, відволікаються від окремо взятого суб'єкта, перетворюючись на загальні універсальні стереотипи поведінки, які вважаються беззастережно схваленими, проголошеними й задекларованими суспільством. Отже, засоби масової інформації мають можливість прищеплювати правила поведінкової культури, демонструючи відповідні моделі, стереотипи, рольові сценарії. Орієнтуючись на безмежно широкий контингент споживачів своєї продукції, вони наділяють правила етикету демократичністю, знімаючи шарові обмеження, елітарність, винятковість у манерах і стилях життя.

Зазначена проблема привертає увагу представників гуманітарного знання. Вона відображена в працях таких авторів, як Ж. Бодрійяр, Г. Йонас, Ю. Габермас, М. Фуко. В останні десятиліття вона в різних ракурсах знайшла відображення в дослідженнях С. Московічі, С. Почепцова, А. Ульяновського, О. Синельникової, а також у роботах вітчизняних фахівців О. Проценко, Н. Корабльової, М. Култаєвої, Е. Мельникової, О. Оленіної, Л. Васильєвої та ін. При цьому проблема ролі ЗМІ у формуванні поведінкової культури залишається відкритою для аналізу з боку філософськоантропологічної рефлексії, а саме етичної іiі інтерпретації, що й стало метою пропонованого дослідження.

Дослідники цієї проблеми звертають увагу, що, ознайомлюючи людину 3 правилами доброго тону й поведінкової культури, масмедіа вільні від дидактики, повчання, нудного моралізаторства, що сприяє більш ефективному залученню до них конкретної особистості. Головним чином продукція масмедіа впливає на первинні соціальні групи (родина, друзі, сусіди, співробітники), де й формуються погляди й переконання, які зумовлюють стратегію поведінкової культури людини.

До безумовних переваг і пріоритетів масмедіа належить комбінаторика в поданні інформації, тобто єдність поведінкової культури й стереотипів візуального, аудіального, вербального. Крім того, у багатьох продуктах масмедіа для ефективності сприйняття пропонованого матеріалу широко використовується низка психологічних прийомів, які підвищують інтерес. Серед них перш за все виділяють уподібнення, тобто явище, коли суб'єкт упізнає себе в образах героїв, переносить події свого життя на сюжет передачі, рекламного ролика, газетної статті тощо. Як особливий прийом також використовується принцип додатковості, коли правила етикету демонструються не самі по собі, а на фоні $з$ іншими явищами соціального життя й наголошується на їх позитивному призначенні. До того ж досить результативною $є$ доступність у поданні найскладніших проблем, пов'язаних із правилами поведінкової культури. Організована особливим чином інформація про правила доброго тону сприймається як започаткована, припустима й навіть бажана. Спираючись на вищезазначені підходи, масмедіа через нагадування й рефрен (повтор) сприяють формуванню морально-психологічного ставлення до декларованого етикету.

Будь-який механізм прихованого впливу, маніпулювання намагається подіяти на іншу свідомість із метою змінити останню, що має проявитися в зовнішніх 
візуальних формах поведінки. Зазначимо, що процеси навіювання виходять за межі раціонального, отже, людина не усвідомлює цього, не сприймає інформацію як таку, що спрямована саме на неї й на певні зміни в її поведінці. Упровадження принципів цивілізованої поведінки ЗМІ пропонують на засадах збіжності традицій, стереотипів наявної культурної поведінки 3 потребами й інтересами споживачів або спираючись на обіцянки задовольнити їх. Особливо ефективними $є$ іманентні, ненавмисні форми сугестії, коли стереотип моральної поведінки формується без відчутного впливу авторитету, влади або чиєїсь безпосередньої волі. Складається враження, що сама людина, на яку націлено навіювання, маніпуляція, починає змінювати зовнішній абрис своїх учинків і дій за власним внутрішнім бажанням.

Зазначимо, що етикет як індикатор поведінкової культури і як своєрідний регулятор зовнішнього аспекту вчинків сам «знаходить» себе в процесі маніпулювання, артикулюючи ввічливість як найбільш коректний засіб передання інформації: іiі використовують у маніпулюванні тоді, коли унеможливлені або вже вичерпані прямі й однозначні засоби впливу. Як правило, під час подання інформації в ЗМІ ввічливість як прийом маніпулювання застосовують у непрямому контексті, коли про щось не можна згадувати, заявляти або вимагати відкрито. У такому випадку експлуатуються різноманітні «виверти»: «риторичні трюки», «лінгвістичні пастки», «символічні винагороди», недомовляння, «дерта лінія» в поданні сюжетної лінії або обговорюванні теми. Зауважимо, що в прихованій пропаганді ввічливість використовують не саму по собі, а через суб'єкта, якому вона належить. Тоді він, як герой програми, взірець та ідеал, несвідомо стає головною фігурою впливу, притягує увагу споживачів масмедіа. Так, за допомогою віртуозного володіння навичками етикету стає можливим кардинально змінювати поведінку адресата, навіювати йому заздалегідь заготовлену лінію поведінки, міняти напрям його думок, формувати погляди, застерігати від небажаних «вивертів» у вчинках i діях. Таким чином ЗМІ залучаються до загальних заходів у формуванні стратегії поведінкової культури через ознайомлення, наочність, навіювання й маніпулювання.

Разом із тим масмедіа здатні й до зворотного ефекту - перешкоджати усвідомленню й формуванню норм етикету, поведінкової культури й спілкування, спрощувати моральні норми, сприяти їх занепаду. Ціла низка сучасних програм нині віддають перевагу висвітлюванню приватного життя на противагу суспільно значущому. Приватне життя, безумовно, може бути предметом масмедіа, якщо це не порушує межі порядного чи пристойного, але ж у гонитві за стійким інтересом споживача на обговорювання виноситься феномени інтимно-особистісного життя, сакраментальне, a згодом i те, що однозначно належить до вульгарного, непристойного, безсоромного й низького. До речі, зауважимо, що зазвичай у програмах відсутні моральні судження, оцінки, принципи. Мова моралі в сучасній продукції масмедіа відсутня як така. Відібрані факти й заготовлені стереотипні реакції на них укладаються в короткий проміжок часу, швидко змінюють одне одного, при цьому не викликаючи почуття причетності до них, що позбавляє 
можливості усвідомити моральну оцінку, сформувати принципи. Такий калейдоскоп подій завдає шкоди як морально-раціональному, так і морально-емоційному.

Сфера морально-психологічних переконань i переживань передбачає рефлексивність, тривалість, поміркованість щодо подій, що зумовлює їх стійкість, продуктивність і дозволяє стати змістом душевного складу людини. Якщо факти, готові стереотипи укладені в короткий проміжок часу, то вони не встигають стати предметом осмислення й обгрунтованих оціночних суджень, не викликають почуття причетності. Спілкування через масмедіа поза живим спілкуванням постає моральним відчуженням та індиферентизмом.

Наголосимо, що у своїх програмах ЗМІ не навмисно відсторонюються від правил поведінкової культури, спрощуючи моральні цінності завдяки розважальній манері їх демонстрації. Стійкі вербальні й візуальні втілення наявних уявлень про добро й зло, честь і гідність, обов'язок і совість та їх перетворення в чемність, делікатність, увічливість не знаходять свого прояву ані в головних акцентах продукції, ані в концептуальних обгрунтуваннях. Приватно-особистісні проблеми переносяться у сферу публічного, набираючи статусу загального й незаперечного. У такий спосіб у продуктах масмедіа здійснюється анонімний диктат у вирішенні проблем моральної культури, при якому декларується вага того, що не є таким насправді. Так, особливою популярністю користуються передачі й матеріали, наповнені непристойними анекдотами, неперевіреними чутками й безсоромними плітками. Феномени суєтності, марності й безплідності життя стають предметом прискіпливої уваги, обговорюються й підносяться до загальнолюдського сенсу існування, не враховуючи ані стать, ані вік, ані смак, ані пріоритетність, ігноруючи будь-які обмеження. У гонитві за притягненням уваги масмедіа усувають найменші обмеження, невимовно закликаючи до вседозволеності, у той час як завданням культурної нормативності 3 моменту iï виникнення була i $\epsilon$ орієнтація на регламентацію всіх різновидів соціальної активності.

Особливе місце в засобах масової інформації зараз належить рекламі. Ідеться не про окремі зразки рекламної продукції, із якою часто ототожнюють рекламу, а про рекламу як унікальне явище сучасної соціальної діяльності, невід'ємний атрибут культури й цивілізації, особливий вид комунікації. Це явище вже давно залишило економічну галузь, у межах якої перш за все народилось і використовувалося й упевнено увійшло в інші сфери суспільного життя, зокрема політику, мистецтво й мораль.

Починаючи 3 XIX ст. рекламна самосвідомість виходить за межі практичних завдань і реклама припиняє функціонувати суто в межах ділової й комерційної діяльності й збагачується іншими варіантами діяльності. Завдяки цілій низці механізмів впливу на споживача вона апелює до глибинних пластів духовного життя як окремої людини, так і суспільства в цілому. Фіксуючи цінність наявних моральних норм, реклама доповнює культурні традиції новими вимогами цивілізації. Сучасна людина покликана сприймати рекламну інформацію як позначки позитивного або негативного, навіть попри те, що їі продукція швидко набридає й викликає реакцію 
відштовхування. Реклама, преса, телебачення усвідомлено чи ні втягуються в транслювання актуального й вагомого, пов'язуючи минуле і сьогодення, класичне i некласичне, елітарне і масове. Артикулюючи нове й більш досконале, реклама долучається до створення такого типу людей, які здатні втілювати штучні форми стану цивілізації, що відповідають вимогам часу.

Зазвичай у рекламі етичний дискурс має посередній характер, виноситься на «другий план». Проте ця його «тіньова» присутність створює особливий ефект: апелювання до прагматичних чинників стає більш переконливим, коли збагачене ідеєю блага. «Чистий чистоган» (пропаганда в неприхованому вигляді), із яким асоціювалася реклама, викоренив себе й сприймається вкрай негативно.

Транслюючи моральні цінності, мотивації, вимоги, реклама збагачує людину практичними прийомами, діями як живим уособленням доброчинності, проявів турботи, допомоги, поваги (онук несе бабусі ліки, син надсилає батькам гроші, дружина опікується чоловіком, сусідка пригощає смаколиками й ділиться секретами кулінарії). Утілюючи причетність (кожен може таке вчинити, так поводитися), наділяючи іiі якоюсь гротескною зворушливістю, реклама вбачає «мораліте» в незначному, повсякденному, іноді банальному, немов «причепурює», прикрашає моральністю будь-які феномени життя. Самовідданість, братерство, солідарність, подвижництво як морально піднесена діяльність проявляють себе в рідкісних, виняткових ситуаціях, які до того ж можуть й не відбутися, а добропорядним (моральною особистістю) бажає себе відчувати кожен. У той же час постійна певна присутність частки морального, хоча б натяку на неї в повсякденних діях, одиничних учинках, які постійно демонструються у рекламі, завжди актуальна й доречна. Реклама показує, що добрі наміри і вчинки не тільки духовно збагачують повсякденне життя, а й прикрашають його. Незважаючи на те що рекламні герої певною мірою гіперболізовані, вони приваблюють і заряджають своєю радістю від отриманого задоволення.

У сучасному світі споживання стає одним із найактивніших модусів відносин, маніфестує себе не тільки в товарах і послугах, а звернене до всіх і всього. Воно здійснює процес єднання, демократизації, навіює думку, що кожен може користуватися тим, чим зараз володіє суспільство, створюючи власний, більш досконалий сучасний стиль життя. Реклама «підштовхує» потенційного споживача на створення нового світу, на вчинок, який відповідає уявленням товариства про культуру й мораль, на можливий ризик «експерименту» й орієнтує на отримання певних результатів. Споживач же, маніпулюючи речами, творить самого себе, навколишнє середовище i, урешті-решт, - власну долю, новий світогляд [2, с. 12-18].

Споживання, нав'язуване рекламою, розширює свої межі, охоплює й споживання «духовного продукту», яке стає можливим завдяки зекономленому часу й заощадженим зусиллям. Цивілізовані види обслуговування сприяють вирішенню моральних проблем. Людина стає користувачем не тільки речей, але й моральних стереотипів. Створювати образ людини не тільки цивілізованої, але й культурної, обізнаної в правилах доброго тону, припустимого й прийнятного 
соціального типу - це супутнє завдання реклами. За допомогою реклами, завдяки акценту на сучасних формах учинків та дій, удало створюється стереотип стилю життя «зі смаком і комфортом», як колись та ж сама реклама створювала образ «елегантного життя». У той же час поведінкова культура використовується самою рекламою для створення міфу про щасливе, безтурботне й безпроблемне життя, у якому спілкування наповнюється маленькими й швидкоплинними радощами від ласощів, подарунків, знахідок, атмосферою доброзичливого й піднесеного настрою. Реклама закликає пізнавати не тільки предметно-матеріальне буття людини, але й ii душевний світ, утілений у конкретному й визначеному індивідуальному бутті. Нормативи поведінкової культури невипадково вводяться в рекламну інформацію. Вони постають знаками пристойного й припустимого, такого, що прийняте в суспільстві. Схвально, декларує реклама, підтримувати чистоту й порядок, стежити за санітарією й гігієною, підтримувати співбесіду, комунікувати, проявляти доброзичливість, займатися спортом чи мистецтвом. Завдяки використанню стереотипу, зразка, моделі, символу рекламі вдається вдосконалювати й змінювати зміст метафори «добрий тон» і формувати стійкий інтерес та турботу про зовнішні форми їі виявлення.

Рекламній продукції як продукту масової культури притаманні засоби клішування й тиражування образності. Поведінкова освіта в рекламі набуває розважального характеру завдяки створенню образу, із яким індивід себе може ідентифікувати, мимоволі переносячи на своє життя ті показники, які в образі проступають найбільш тенденційно. Особливого ефекту набуває, так би мовити, запрошення повторювати, наслідувати, імітувати. Ця мета досягається тоді, коли життєва програма подається найбільш виразно й красиво, асоціюється 3 позитивними переживаннями наявного або очікуваного блага. Поряд із образністю реклама широко застосовує алегоріі, які розкривають внутрішні душевні якості людини або цінності соціального життя (авторитет, силу, владу, успіх тощо).

Таким чином, продукти ЗМІ переносять акцент із послуг на особистість. У цій ситуації важливо, щоб особа, яка сприймає цю продукцію, прагнула жити в тій системі речей і послуг, удосконалювати своє життя й себе саму. У зв’язку 3 цим залучається безліч нових модуляцій дій, учинків і стосунків, що персоніфікують продукцію ЗМI, зокрема рекламу. Як зазначає Ж. Бодрійяр: «Нині народилася нова мораль: мораль випереджаючого споживання по відношенню до накопичення, мораль утікання вперед, форсованого інвестування, прискореного споживання і хронічної інфляції...» [1, с. 133].

Створюючи міф про об'єктивну користь, реклама використовує етикетні прийоми, щоб інформація подавалася бездоганно делікатно, коректно, щоб не образити й не уразити інших. Життєвих ситуацій, що викликають осуд, конфуз, 
інтимні проблеми, - ось чого можна уникати, використовуючи рекламне іносказання. Реклама стверджує, що можна оприлюднити потаємне, суто особистісне, якщо робити це вкрай ввічливо, задля того щоб допомогти позбутися недоліків, удосконалюватися. Сюжет реклами може допомогти щось зрозуміти, напоумити, підказати правильне рішення, навіяне здогадкою.

Таким чином, рекламна інформація компенсує недолік культури в реальному житті. Реклама сама по собі не має певно визначеного адресата, вона проголошує нейтрально, що й зумовлює ненав'язливе, безадресне повчання: варто (комусь) бути охайним, стежити за манерами, висловлюваннями, гарно поводитися, поважати старших тощо. При цьому долучається думка, що на кожного дивляться, кожен може подобатися й ставати кращим. Демонстрація поведінкової культури в рекламі сприяє соціальній активності індивіда. «Усе більш і більш опираючись рекламному імперативу, ми натомість стаємо більш чутливими до рекламного індикативу, тобто до самого факту існування реклами як вторинного споживчого товару й певного явища певної культури», пише Ж. Бодрійяр [1, с. 37].

Розважальність і розчуленість, які дарує реклама, іiі нав’язлива присутність завжди і всюди можуть безумовно негативно позначатися на ii сприйнятті, викликаючи відторгнення й навіть протест. Серед дорікань рекламі висувають також і зайву експлуатацію кліше, розхожих і заяложених методів залучення адресатів, а також солодкуватість, глянець, блиск і награність у поведінці героїв. Вона підкуповує тим, що відображає прагнення жити й світі не тільки зручному й красивому, але й у такому, який наповнений увічливим і чемним поводженням, так само як він наповнений ярликами, товарними знаками, коментарями. Культурно-поведінкова бездоганність у невербальному й вербальному спілкуванні (маскування непристойного, відмова від нудного моралізаторства тощо) стає настільки ж привабливою, як і рекламовані речі й послуги. Навіть якщо в рекламі й присутня ідеалізація форм поведінкової культури, яка не реалізується в дійсності, то вона хоча б задана як модель, зразок, без якого немислима культура споживання в цивілізаційному суспільстві.

Отже, на сучасному етапі розвитку суспільства 3МI, зокрема через рекламу, постають оригінальним способом неявного примусу, навіювання до наслідування норм поведінкової культури, пропонуючи моделі, стереотипи, рольові сценарії. I хоча вони не мають наміру змінювати наявні правила доброго тону, належної поведінки, проте результати діяльності 3МІ через притаманні їм методи прихованого пропагування й маніпулювання сприяють (свідомо або ні) створюванню нових стереотипів поведінки, інших форм виявлення моральності й доброчинності, які більш відповідають новим потребам і інтересам суспільства та людини. 
Література:

1. Бодрійяр Ж. Система вещей. М., 1995. 258 с.

2. Бодрійяр Ж. Общество потребления. М., 2006. 269 с.

3. Московічі C. Стратегія пропаганди i колективного навіювання // URL : http ://www.ji.lviv.ua/n30texts/moskovichi.htm

\section{References:}

1. Bodrlyyar, Zh. (1995) Sistema veschey. [System of things]

2. BodrIyyar, Zh. (2006) Obschestvo potrebleniya [Consuming Society]

3. MoskovIchI S. StrategIya propagandi I kolektivnogo navIyuvannya [Propaganda and collective suggestion strategy], available at : http://www.ji.lviv.ua/n30texts/moskovichi.htm

Chykhyn Svitlana - Ph.D., Associate Professor, Associate Professor of the Department of Law Faculty of Humanities of the National Aerospace University «Kharkiv Aviation Institute».

Чмихун Світлана - кандидат філософських наук, доцент, доцент кафедри права гуманітарного факультету Національного аерокосмічного університету ім. М.С. Жуковського «XАI» (м. Харків).

e-mail: Svitlana.chykhyn@gmail.com

Bilchuk Natalia - Candidate of Philosophy. Associate Professor. Heard of the Department of Philosophy of the National Aerospace University «Kharkiv Aviation Institute».

Більчук Наталя - кандидат філософських наук, доцент, виконувач обов’язків завідувача кафедри філософії Національного аерокосмічного університету ім. М.Є. Жуковського «Харківський авіаційний інститут».

e-mail:n.bilchuk@khai.edu

\section{Svitlana Chmykhun, Natalja Bilchuk}

\section{MASS MEDIA AS AGENT OF IMPLICIT ENFORCEMENT OF BEHAVIORAL CULTURE}

The media have the ability to detect, store and transform information about stereotypes of behavioral culture, civilized forms of manifestation, both in everyday life of people, and in institutional relations, especially in the business and diplomacy sectors. In their role diversity, the media may implicitly enforce to such standards of behavior that society requires for organized, orderly relationships and compliance with social morals.

Nowadays, the media possess unique means of suggestion, persuasion, propaganda and 
manipulation of the audience. In this process, the mechanism of influence of consciousness is of particular importance in order to change the outer scope of its behavior. At the same time, the media have a number of advantages: the mass media are free of didactics, instruction and tendentious moralisation. Unconditional advantages of the mass media include combinatorics when providing information about the rules of good tone, polite behavior. Many products of the media are widely used in psychological techniques that facilitate the assimilation of information provided, for example, assimilation and recognition. Immanent, unintentional forms of suggestion are also effective, when stereotypes of behavior that correspond to representations of decency are formed without a tangible influence of authority, power or fear of punishment.

Moreover, the media are capable of the opposite effect - to simplify, deform the patterns of behavioral culture and relationships, and contribute to the simplification of morality. Such areas in the activities of the media include violation of limits of the decent, mocking sacramental (sacred), turning to vulgar and obscene themes. In pursuit of the attention mass media are able to eliminate restrictions, unvoluntarily call for permissiveness. Such a role in the media is played by advertising, which can adjust to unpretentiousness and easiness, as well as demonstration in programs such things that are clear and desirable to the majority. In this case the stereotypical form of behavior acts through allegorical figures, influencing the individual's subconsciousness.

The article analyzes the place and role of mass media in the formation of stereotypes of behavioral culture. As a result of the study, the conclusion was made about the dual nature of mass-media production: on the one hand, they implicitly influence the spread of etiquette rules, and on the other hand, they can contribute to the simplification of morality and indulge vulgar, obscene, low-lying and impenetrable behaviour.

Keywords: suggestion, manipulation, mass media, behavioral culture.

\section{Світлана Чмихун, Наталя Більчук}

\section{ЗМІ ЯК АГЕНТ НЕЯВНОГО ПРИМУСУ ПОВЕДІНКОВОЇ КУЛЬТУРИ}

Засоби масової інформації мають здатність виявляти, зберігати й трансформувати інформацію про стереотипи поведінкової культури, цивілізовані форми іiї прояву як у повсякденному житті людей, так і в інституційних відносинах, особливо у сфері бізнесу й дипломатії. У своєму рольовому різноманітті ЗМІ можуть неявно примушувати до таких стандартів поведінки, яких потребує суспільство для організованих, упорядкованих відносин і які відповідають нормам суспільної моралі.

На сьогодні 3МІ володіють унікальними засобами навіювання, переконання, пропагування й маніпулювання аудиторією. У цьому процесі особливе значення має механізм впливу свідомості з метою змінити зовнішній абрис її поведінки. При цьому ЗМІ мають цілу низку переваг: масмедіа вільні від дидактики, повчання й тенденційного моралізаторства. До безумовних «плюсів» масмедіа належить комбінаторика в поданні інформації про правила доброго тону, увічливого поводження. У багатьох продуктах ЗМІ широко використовуються психологічні 
прийоми, які сприяють засвоєнню інформації, що подається, наприклад, уподібнення й упізнавання. Ефективні також іманентні, ненавмисні форми сугестії, коли стереотипи поведінки, які відповідають уявленням про пристойність і порядність, формуються без відчутного впливу авторитету, влади або остраху покарання.

Разом із тим масмедіа здатні й до зворотного ефекту - спрощувати, деформувати схеми поведінкової культури й відношень, сприяти спрощенню норм моралі. До таких напрямків у діяльності 3МІ належать порушення меж пристойного й порядного, висміювання сакраментального (сакрального), звернення до вульгарних i непристойних тем. У гонитві за приверненням уваги масмедіа здатні усувати обмеження, невимовно закликати до вседозволеності. Таку роль у засобах масової інформації відіграють реклама, налаштовуючи на невибагливість і легкість, а також демонстрація в програмах того, що зрозуміло й бажане багатьом. Тоді стереотипна форма поведінки скоріше проступає через алегоричні фігури, швидше впливаючи на підсвідомість індивіда.

У статті проаналізовано місце й роль ЗМІ у формуванні стереотипів поведінкової культури. У результаті дослідження було зроблено висновок про подвійний характер продукції масмедіа: 3 одного боку, вони неявно впливають на розповсюдження правил етикету, а з другого - можуть сприяти спрощенню моралі й потурати вульгарному, непристойному, низькопробному.

Ключові слова: навіювання, маніпуляція, масмедіа, поведінкова культура.

...A насправді, чи варто сьогодні піднімати питання про те, яка роль філософії в добуванні сучасного знання? Чи питання більш глобальне: навіщо взагалі потрібна філософія в суспільстві «чорних дзеркал», нескінченного калейдоскопу новинних стрічок, фотографій, інстаграмів? Діалектика відповідей (від «невимовної неприязні технарів до філософії» А. Войтова, «філософської метушні на узбіччі науки» Р. Фейнмана до «потреби в філософії» В.Гейзенберга $i$ В. фон Гумбольдта) дозволяє сконструювати картину людського буття, де два світовідчуття проектують своє ставлення до Свободи створювати. Опановувати філософію, шанувати мудрість, схилити голову перед величчю досвіду попередніх -- ие є шлях до своєї Свободи. Свободи мислити, аналізувати, приймати рімення, падати і знову підніматися.

Кафедрі філософії нашого університету - 40 років. Правоохорониям Свободи Думки Кіму Олексійовичу Байрачному, Ользі Петрівні Проченко, Анатолію Юрійовичу Кузнечову, Євгенії Петрівні Корогодовій, Камілю Магомедовичу Магомедову, Ользі Вікторівні Ковалевській, Людмилі Василівні Рязанцевій - низький уклін за науку думати і розуміти. Їх учням і послідовникам - сили Духу, сили Любові і прощення в цей дуже непростий час.

Чмихун С. Є. - кандидат філософських наук, доцент. Працює на кафедрі права (на той час історії і політологіï) з 1999 р. Захистила кандидатську дисертацію під керівництвом Копилова В.О.

Більчук Наталя Леонідівна, кандидат філософських наук, доцент, виконувач обов'язків завідувача кафедри філософії. Після закінчення історичного факультету Харківського національного університету працює на кафедрі філософії вже двадцять 
років, тобто пройшла шлях від асистента до виконувача обов'язків завідувача кафедри. На цій кафедрі вчилася в аспірантурі й готувала дисертацію під науковим керівництвом Байрачного К. О.

Надійшла до редакції 11.03.2019. Розглянута на редколегії 18.03.2019.

\section{Рецензенти:}

Доктор філософських наук, професор кафедри філософії Національного аерокосмічного університету ім. М.Є. Жуковського «ХАІ» Кузнеиов А.Ю.

Кандидат філософскіх наук, доцент, завідувач кафедри права Начіонального аерокосмічного університету ім. М.С. Жуковського «ХАІ» Селевко В.Б. 